\title{
Gap junction communication dynamics and bystander effects from ultrasoft X-rays
}

\author{
GO Edwards', SW Botchway', G Hirst', CW Wharton', JK Chipman' and RA Meldrum*, \\ 'School of Biosciences, The University of Birmingham, Edgbaston, Birmingham B I 5 2TT, UK; ${ }^{2}$ Rutherford Appleton Laboratory, Chilton, Oxfordshire OXI I \\ OQX, UK
}

An increasing number of experimental observations reveal that toxic effects can be spread between cells in multicellular organisms even when neighbouring cells have not come into contact with the toxicant. This phenomenon is facilitated by several different cellular pathways, which are collectively known as the 'bystander' effect (Mothersill and Seymour, 2001).

It is easily appreciated how important it is to understand this phenomenon since the effects of toxicants might be underestimated if a direct dose relationship is assumed. This is of particular concern when considering the dose-response relationship and risk assessment of radiation. Radiotherapy is a common cancer treatment, and an accurate knowledge of dose-response relationships is vital to ensure successful treatment without endangering the patient. Furthermore, bystander effects in radiation therapy may augment the killing effects of radiation in tumour therapy (Chipman et al, 2003). Following radiation exposure, toxic factors might be spread or transferred by diffusion through aqueous media in organisms or cell cultures or may involve connexin-mediated gap junction intercellular communication (GJIC) (Mothersill and Seymour, 2001). Pinpointing the actual mechanism responsible for a bystander effect forms a major challenge.

The basic subunit of the gap junction is the connexin protein, and to date 21 different connexins have been cloned (Willecke et al, 2002). Six connexins form a hexamer around a central pore called a

*Correspondence: RA Meldrum; E-mail: r.meldrum@bham.ac.uk Received 4 November 2003; revised 8 January 2004; accepted 12 January 2004; published online 2 March 2004 connexon, which is trafficked to the extracellular membrane (Evans and Martin, 2002). Gap junctions are formed when connexons on adjacent cells dock to form a pore between cells, allowing cytoplasmic continuity. The structure and function of gap junctions have recently been reviewed (Evans and Martin, 2002; Chipman et al, 2003). Gap junctions allow direct passage of molecules between cells, by a process known as GJIC. Closure of gap junctions has previously been described as involving changes in connexin phosphorylation (Lampe and Lau, 2000; Rivedal and Opsahl, 2001).

The bystander effect is of importance in cancer gene therapy (Molten, 1986) as GJIC mediates the transfer of gene products from transfected into nontransfected cells resulting in cell death. Transfection of cells with the herpes simplex virus thymidine kinase gene followed by treatment with the nucleotide analogue ganciclovir (GCV) results in phosphorylation of GCV. Phosphorylated GCV is incorporated into cells' DNA terminating DNA replication, leading to cell death. This is enhanced in cells transfected with functional connexin genes as it is thought that phosphorylated GCV may pass through gap junctions (Tanaka et al, 2001). A current research approach to cancer treatment involves the combination of chemotherapy and radiotherapy (Patterson et al, 2003): if chemotherapeutic metabolites are required to pass from cell to cell to result in bystander killing, then knowledge of the effects of radiation on gap junctions is desirable. Gap junction intercellular communication has also been implicated in the inter-cell transfer of radiation effects (Azzam et al, 1998; Zhou et al, 2002). Bystander cells express the stressinducible protein $\mathrm{p} 21^{\text {Waf1 }}$, micronucleus formation and p53 phosphorylation dependent on functional GJIC (Azzam et al, 
2001). What makes it difficult to distinguish clearly between GJIC mechanisms and other mechanisms of transfer in cells exposed to chemicals or radiation is the lack of precise control over the regions of cells directly exposed. Radiation is ideally confined within a single cell's boundaries if gap junction transport is to be studied.

Low-energy ultrasoft X-rays provide an ideal source of radiation for this purpose because their properties allow spatial definition of exposed regions in a sample. Development of a laser plasmagenerated ultrasoft X-ray source began in the late 1980s (Turcu et al, 1990, 1994). The source uses a system of excimer lasers, which produces a train of picosecond pulses. These are focused down to a $10 \mu \mathrm{m}$ spot onto a moving tape of a target material. The ablation of the material, which is heated typically to $10^{7} \mathrm{~K}$, results in the thermal generation of X-rays. The target material can easily be changed and thus the system is capable of generating X-rays of different wavelengths. The material used for exposure of cells was copper, which gives rise to $1.1 \mathrm{keV} 1.2 \mathrm{~nm}$ X-rays. Cells were grown on Hostaphan of $1 \mu \mathrm{m}$ thickness, and the penetration of the X-rays into the cells was less than $5 \mu \mathrm{m}$ (Goodhead and Thacker, 1977). The energy of the X-rays is so low that the interaction of the radiation with cellular components only takes place in cells on which the radiation directly impinges. The X-ray spectrum from the laser plasma source is sufficiently soft for long-range scattering to be very weak. This ensures that radiation of the surrounding medium is avoided so that radiolysis products from this source will not complicate the experiments.

Studies on the radiation bystander effect, which imply that GJIC plays a major role in spreading the effects of radiation, have used $\alpha$-particle radiation (Azzam et al, 1998, 2001), which is high linear energy transfer (LET) radiation and will penetrate the full depth of a cell. The current study uses low LET radiation, and the tracks have an attenuation length of only $3.4 \mu \mathrm{m}(1 / \mathrm{e})$, which ensures that the radiation will be fully absorbed within the cell.

To investigate the effects that radiation has on the function of gap junctions in directly irradiated and bystander cells, we have combined pulsed-laser plasma-generated ultrasoft X-rays (Turcu et al, 1990, 1994), micropositioning technology and photobleaching of single dye-loaded cells. We define a dose-response relationship and the spatial extent of the responses to localised irradiation in cultured cell populations. Changes in the phosphorylation of connexin43 (Cx43) have also been investigated.

\section{MATERIALS AND METHODS}

\section{Cell culture}

Rat liver epithelial cells (WB-F344, a kind gift from Professor WB Coleman) were cultured in improved minimum essential medium (Biosource International, Nivelles, Belgium) supplemented with $2 \mathrm{~mm}$ glutamine (Sigma Chemical Co., Poole, Dorset, UK), $5 \% \mathrm{vv}^{-1}$ foetal calf serum (Labtech International, Ringmer, East Sussex, UK) and $50 \mu \mathrm{g} \mathrm{ml}^{-1}$ gentamicin (Sigma). Cultures were incubated at $37^{\circ} \mathrm{C}$ in $5 \% \mathrm{CO}_{2} / 95 \%$ air. Cells were passaged every $3-4$ days, when confluent, via trypsinisation. These cells express $\mathrm{Cx} 43$ and are competent in GJIC (Stock et al, 1998).

\section{Irradiation of cells with ultrasoft X-rays}

In order to expose cells to ultrasoft X-rays, they were cultured in chambers constructed from $35 \mathrm{~mm}$ diameter glass rings fitted with a $1 \mu \mathrm{m}$ thick Hostaphan base (Hoechst). The X-rays were generated from a laser plasma source as described previously (Meldrum et al, 2002). A $25 \mu \mathrm{m} \times 3 \mathrm{~mm}$ slit was manufactured in a disc of stainless steel of $13 \mu \mathrm{m}$ thickness. This disc was fitted into the wall of the chamber directly above the point of the laser plasma. The stainless steel is completely opaque to the $1.1 \mathrm{keV}$ X-rays. An aluminium filter ( $3 \mu \mathrm{m}$ thick) placed between the X-ray source and the X-ray outlet excludes all visible and UV light.

Dishes of cells were placed in a chamber holder that could be seated in six predetermined positions on the X-ray source and exposed to 1,3 or $5 \mathrm{~Gy}$ soft X-rays. It has previously been shown that a dose of 5 Gy caused extensive cytotoxicity to V79-4 Chinese hamster ovary cells, through a delayed mechanism resulting from DNA damage and measurable by colony formation at 7 days postirradiation (Botchway et al, 1997). Both the X-ray source stage and the confocal microscope stage were modified by the addition of a series of recesses, allowing the chamber holder to be positioned by means of triangulation between three points. The stage on the confocal microscope was controlled by a computer running an 'in-house' program (programmed on LabVIEW ${ }^{\mathrm{TM}}$ ). Six regions of illumination were defined, detected on Gaffchromic film, and the confocal stage was calibrated using this so that the computer could send the stage to an exact region of illumination. By doing this, it was possible to reposition the stage to investigate both directly irradiated cells and cells a known distance from the illuminated region.

\section{GapFRAP}

Gap junction intercellular communication was monitored using the GapFRAP (fluorescence redistribution after photobleaching via gap junctions) technique (Frame and de Feijter, 1997; Cotrina et al, 1998). Confluent cultures of cells were washed twice with phosphate-buffered saline (PBS) and placed in medium containing $10 \mu \mathrm{m}$ 5,6-carboxyfluorescein diacetate (CFDA) (Molecular Probes, Cambridge Biosciences, Cambridge, UK). These were incubated for $15 \mathrm{~min}$ at $37^{\circ} \mathrm{C}$, after which they were washed three times in PBS, and placed under supplemented culture medium prior to irradiation. Cells were examined with a $\times 20$ objective, and fluorophores excited with a $25 \mathrm{~mW}$ argon-ion laser $(488 \mathrm{~nm})$. A field of view containing confluent fluorescing cells was selected and an image captured ('prebleach'). Using the zoom function on the confocal microscope, a single cell was selected and five passes of the argon-ion laser, operating at full power $(<1 \mathrm{~mW}$ at the microscope stage), bleached the dye in this cell. The microscope was returned to the previous configuration and an image, 'postbleach', was captured. At 4 min postbleaching, a final image was captured. Treatments were replicated 9-11 times. The degree of redistribution of fluorescence into the photobleached cell was determined using the ScionImage computer program (Scion Corporation, Frederic, Maryland, USA).

\section{Phosphorylation of $\mathrm{Cx} 43$}

Whole dishes of cells were exposed to $5 \mathrm{~Gy}, 1.1 \mathrm{keV}$ ultrasoft $\mathrm{X}$-rays. Cells were scraped into PBS, pelleted, frozen in liquid nitrogen and stored at $-70^{\circ} \mathrm{C}$. As a positive control for hyperphosphorylation (Rivedal and Opsahl, 2001; Yang et al, 2001), dishes

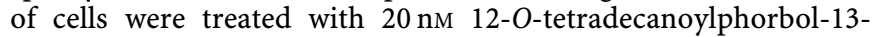
acetate (TPA) for $15 \mathrm{~min}$ and collected in the same manner as irradiated cells. For analysis, pellets were thawed and resuspended in $100 \mu \mathrm{l}$ lysis buffer $\left(1 \% \mathrm{w} \mathrm{v}^{-1}\right.$ SDS, $1 \mathrm{~mm}$ sodium vanadate, $10 \mathrm{~mm}$ Tris-HCl, $\mathrm{pH}$ 7.4) and disrupted by passing repeatedly through a $25 \mathrm{G}$ syringe. Total protein in a $10 \mu \mathrm{l}$ aliquot was determined by the BioRad $D_{c}$ assay (BioRad, Hemel Hempstead, Hertfordshire, UK), and compared against a standard curve of bovine serum albumin (Sigma). An aliquot of sample containing $15 \mu \mathrm{g}$ total protein was mixed at a ratio of $1: 1$ with reducing sample buffer $(0.125 \mathrm{M}$ Tris$\mathrm{HCl}, \mathrm{pH} 6.8 ; 20 \% \mathrm{wv}^{-1}$ glycerol; $5 \% \mathrm{wv}^{-1}$ SDS; $5 \% \mathrm{vv}^{-1} \beta$ mercaptoethanol; $0.1 \% \mathrm{w} \mathrm{v}^{-1}$ bromophenol blue) and incubated for $10 \mathrm{~min}$ at room temperature. Electrophoresis was carried out on $12.5 \%$ SDS-polyacrylamide gels (Laemlli, 1970). Control gels were stained with Coomassie blue to assess protein separation. Proteins were transferred to Hybond-C Extra membrane 
(Amersham Biosciences, Little Chalfont, Buckinghamshire, UK), which was blocked for $1 \mathrm{~h}$ at room temperature with $5 \% \mathrm{w} \mathrm{v}^{-1}$ skimmed milk powder in TBST (10 mM Tris- $\mathrm{HCl}, \mathrm{pH} 8.0 ; 150 \mathrm{~mm}$ $\mathrm{NaCl} ; 0.05 \%$ Tween-20), and probed for $1 \mathrm{~h}$ with a mouse anti-ratCx43 primary antibody (BD Pharmingen, Cowley, Oxfordshire, UK). Blots were then stained with a horseradish peroxidaseconjugated goat anti-mouse secondary antibody (DakoCytomation, Ely, Cambridgeshire, UK) and detected by the enhanced chemiluminescence method (Amersham).

\section{Assessment of cell membrane integrity}

Dishes of cells were exposed to 1, 3, 5 and 10 Gy soft X-rays and incubated under standard growth conditions for $30 \mathrm{~min}$ and $2 \mathrm{~h}$. Following incubation, the culture medium was collected and assayed for lactate dehydrogenase (LDH) activity (Moldeus et al, 1978). To a cuvette, $530 \mu \mathrm{l}$ potassium phosphate buffer was added $\left(66 \mathrm{mM} \mathrm{K}_{2} \mathrm{HPO}_{4}, 34 \mathrm{mM} \mathrm{KH}_{2} \mathrm{PO}_{4}\right.$, pH 7.0), along with $50 \mu \mathrm{l} 23 \mathrm{~mm}$ sodium pyruvate. The supernatant from the cell cultures $(400 \mu \mathrm{l})$ was added. Finally, $10 \mu \mathrm{l}$ of a $12 \mathrm{~mm}$ NADH solution (freshly prepared and stored on ice) was added, and cuvettes were mixed by inversion. The decrease in absorption at $340 \mathrm{~nm}$ over $30 \mathrm{~s}$ was measured, giving an indication of LDH activity. Cells were scraped from Hostaphan membranes, lysed in lysis buffer, and solids were pelleted out by microcentrifuging samples for $1 \mathrm{~min}$ at 13000 r.p.m. Total protein was measured with the BioRad $D_{c}$ assay. Controls consisted of untreated cells and cells treated with $0.5 \% \mathrm{v} \mathrm{v}^{-1}$ Triton X-100. The latter provided a positive control for $100 \% \mathrm{LDH}$ leakage. Data were expressed as relative LDH activity, calculated by dividing LDH activity by the total protein per dish. Treatments were carried out in triplicate and differences analysed using the $t$-test.

\section{RESULTS}

\section{Spatial irradiation of cells}

Figure 1A shows the image obtained when Gaffchromic film was exposed to $400 \mathrm{~Gy}$ of $1.1 \mathrm{keV}$ X-rays, through a $100 \mu \mathrm{m}$ slit. The area of cells irradiated in a confluent culture can be determined by overlaying the cell culture dish on the exposed film (Figure 1B). If used in conjunction with the micropositioning and relocation system, it is possible to confirm exactly where and how many cells were irradiated. This helps to choose a cell to photobleach for GapFRAP analysis as it enables cells to be located both within the exposed region and at defined distances from exposed cells. As well as providing precise spatial control over cells irradiated, the pulsed nature of the ultrasoft X-ray source allows the dose of Xrays to be controlled, and as the system is capable of delivering $3 \mathrm{~Gy} \mathrm{~s}^{-1}$, a substantial dose may be given in a short time.

\section{GapFRAP analysis}

Glycyrrhetinic acid was used as a positive control as it is known to inhibit GJIC (Goldberg et al, 1996; Tare et al, 2002). This provides a negative index against which the extent of fluorescence redistribution after photobleaching in irradiated cells can be compared. Fluorescence redistribution in untreated cells provides a positive index of GJIC. Figure $2 \mathrm{~A}$ shows the fluorescence redistribution 1 and 4 min after photobleaching of a single cell in untreated cells and cells treated with $25 \mu \mathrm{M} 18 \alpha$-glycyrrhetinic acid for $30 \mathrm{~min}$. To derive an index of fluorescence redistribution, fluorescence intensity was measured in the unbleached cell and the fluorescence intensity $4 \mathrm{~min}$ after photobleaching is expressed as a percentage of the initial fluorescence content of the cell. In the untreated cells, the fluorescence recovered to approximately $20 \%$ of the initial value within $4 \mathrm{~min}$, but in the $18 \alpha$-glycyrrhetinic acidtreated cells this only recovered to $6 \%$ of the initial value.
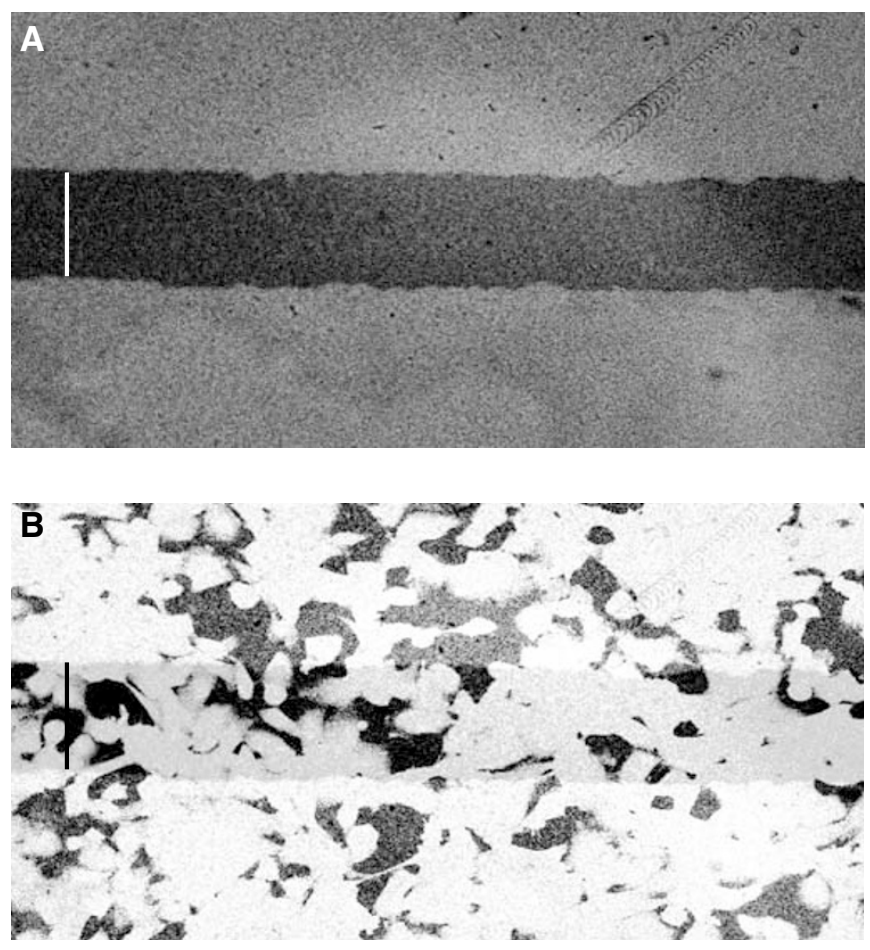

Figure I (A) Micrograph of Gaffchromic film illuminated with $400 \mathrm{~Gy}$ ultrasoft X-rays, demonstrating a sharply defined region of irradiation. Bar represents $100 \mu \mathrm{m}$. (B) Fluorescently labelled cells were overlaid on the film to demonstrate how many cells are exposed to ultrasoft $X$-rays and confirm that translation from the $X$-ray source to the confocal microscope relocated irradiated cells accurately. Bar represents $100 \mu \mathrm{m}$.

A baseline comparison was derived from sets of control untreated cells for each individual experiment. The value of fluorescence redistribution in irradiated cells is henceforth described in terms of a percentage of the redistribution that takes place in the matched set of untreated cells.

\section{Effects of ultrasoft X-irradiation on intercellular communication}

Cells were loaded with CFDA and irradiated through the $100 \mu \mathrm{m}$ slit with 1,3 and 5 Gy ultrasoft X-rays. GapFRAP was carried out at 3 and 15 min postirradiation (Figures $2 \mathrm{~B}, 3 \mathrm{~A}, \mathrm{~B}$ ). The fluorescence in cells $4 \mathrm{~min}$ postbleaching was recorded. At $3 \mathrm{~min}$ postirradiation, exposure of cells to $1 \mathrm{~Gy}$ reduced the recovery of fluorescence in the photobleached cells to $82.8 \pm 7.1 \%(P=0.057)$ of initial values, $3 \mathrm{~Gy}$ to $54.5 \pm 5.5 \%(P<0.01)$ and $5 \mathrm{~Gy}$ to $24.0 \pm 5.4 \%$ $(P<0.001)$. The inhibition of intercellular communication by $5 \mathrm{~Gy}$ ultrasoft X-rays was comparable in magnitude to that induced by $25 \mu \mathrm{M} 18 \alpha$-glycyrrhetinic acid. At $15 \mathrm{~min}$ postirradiation, the inhibitory effects were still apparent and became statistically significant at $1 \mathrm{~Gy}$ but were similar or reduced ( $15 \mathrm{~min}$ compared to $3 \mathrm{~min}$ ) at 3 and $5 \mathrm{~Gy}$.

\section{GapFRAP analysis of bystander cell communication}

Cultures of confluent cells were irradiated through the $100 \mu \mathrm{m}$ slit, and GapFRAP analysis of unirradiated 'bystander' cells was carried out at a distance of $100 \mu \mathrm{m}$ from the irradiated cells. Reduction of communication between these cells was detected but was of a lesser magnitude at $3 \mathrm{~min}$ postirradiation than in the directly irradiated cells (Figure 4A). Communication in bystander cells after treatment with $1 \mathrm{~Gy}$ ultrasoft $\mathrm{X}$-rays was reduced to $78.9 \pm 5.9 \% \quad(P<0.05)$ of that in untreated cells, $3 \mathrm{~Gy}$ to 
A
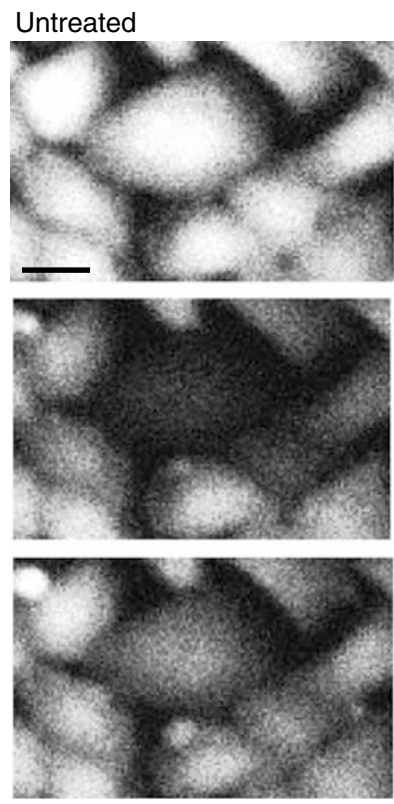

$18 \alpha \mathrm{GA}$
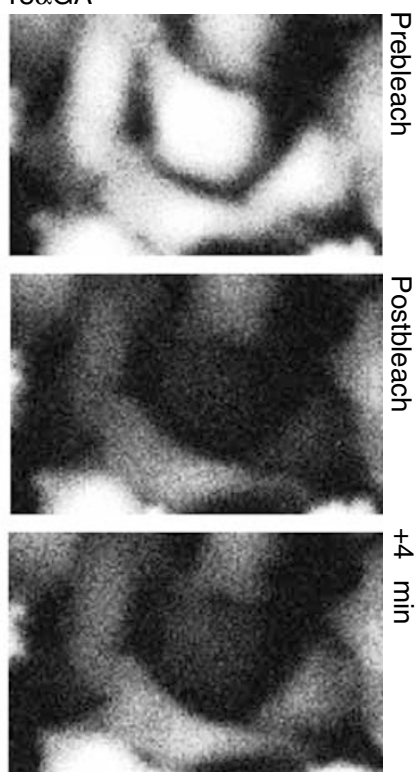

\section{B}
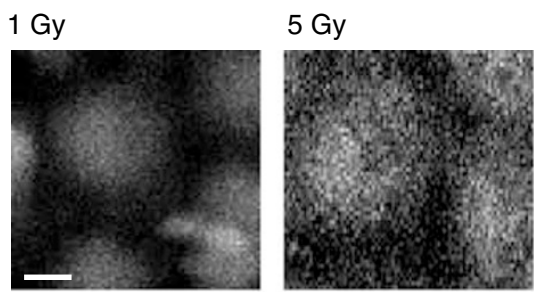

MT 5 Gy
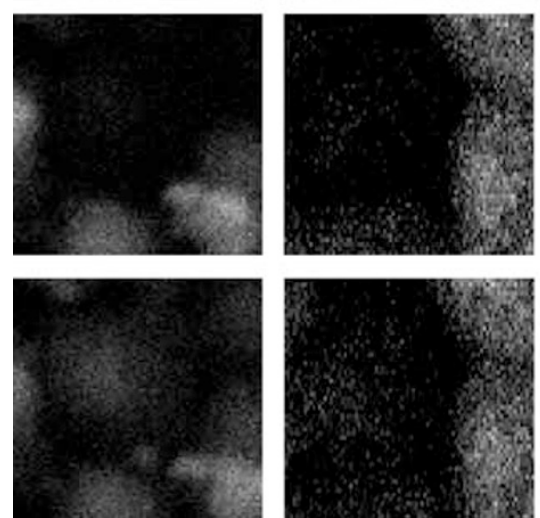

A

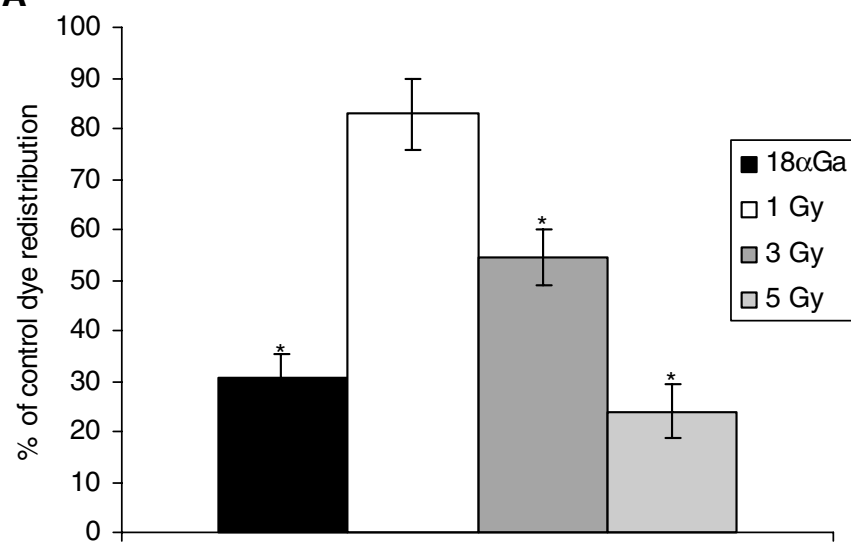

B

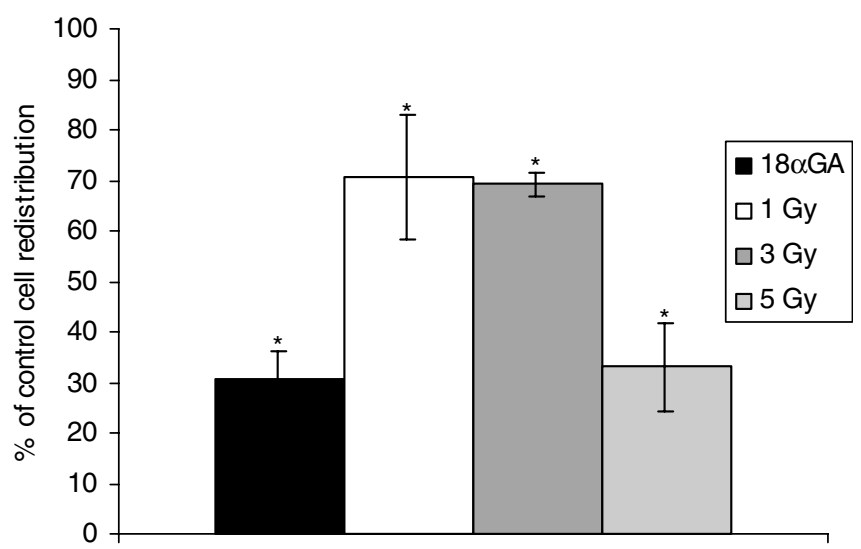

Figure 3 Dose-response relationship between dose of ultrasoft $X$-rays and gap junction communication (rate of redistribution of fluorescence in the GapFRAP assay) in directly irradiated WB-F344 rat liver epithelial cells at (A) 3 min and (B) 15 min postexposure, compared to cells treated with $25 \mu \mathrm{M} \mid 8 \alpha$-glycyrrhetinic acid (I $8 \alpha \mathrm{GA}$; gap junction inhibitor). Results are expressed as \% communication compared to control (untreated) cells (5.022 $\left.\cup \mathrm{min}^{-1} \pm 0.275\right)$. Bars show standard error of the mean.

\section{Studies on the potential transfer of effects via the medium}

To establish if the inhibition of GJIC in bystander cells could occur via an intercellular signal released into the medium, two further experiments were carried out. Whole dishes of confluent cells were exposed to $5 \mathrm{~Gy}$ ultrasoft X-rays and the medium transferred to dishes of nonirradiated confluent cells, 3 and 15 min postirradiation. Recipient cells were assayed for GJIC using GapFRAP up to 15 min after addition of medium from irradiated cells. GapFRAP demonstrated that communication in the recipients was not significantly different from that observed in untreated cells (Figure 5A).

To investigate if a medium-borne factor could exert an effect on cells in close proximity to (but not in contact with) irradiated cells, cultures were seeded in $3 \mathrm{ml}$ medium in growth chambers at $10^{4}$ cells ml $\mathrm{m}^{-1}$ and cultured for $24 \mathrm{~h}$. These conditions provided small clusters of cells isolated from each other. Samples were then irradiated with $5 \mathrm{~Gy}$ ultrasoft X-rays through the $100 \mu \mathrm{m}$ slit, and the micropositioning system employed so that GapFRAP could be carried out on clusters of nonirradiated cells approximately $100 \mu \mathrm{m}$ from (yet not confluent with) the irradiated cells. A transfer of effects on GJIC was not observed under these conditions (Figure 5B).
$59.3 \pm 5.1 \%(P<0.01)$ and $5 \mathrm{~Gy}$ to $69.0 \pm 10.0 \%(P<0.01)$. This illustrates a lack of a proportional relation with the dose of irradiation in bystander cells. A slight further suppression of intercellular communication was evident at $15 \mathrm{~min}$ postirradiation (Figure 4B), sufficient to make the effect of $1 \mathrm{~Gy}$ exposure statistically significant. 
A

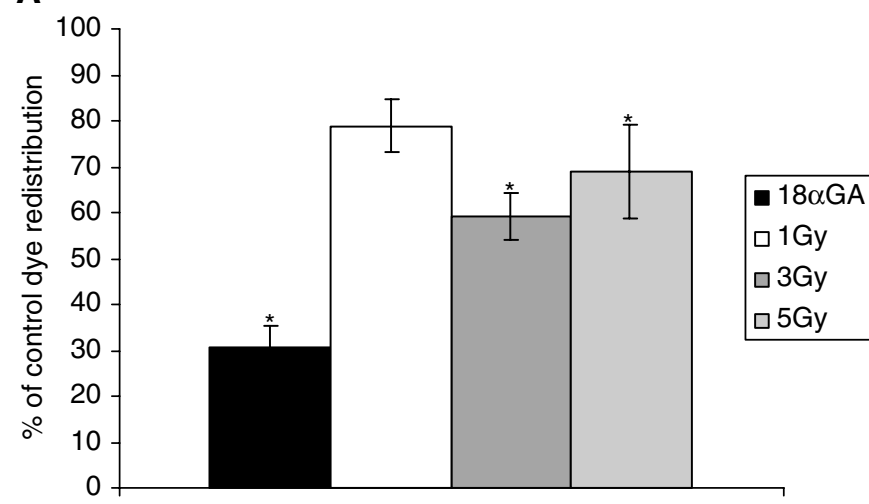

B

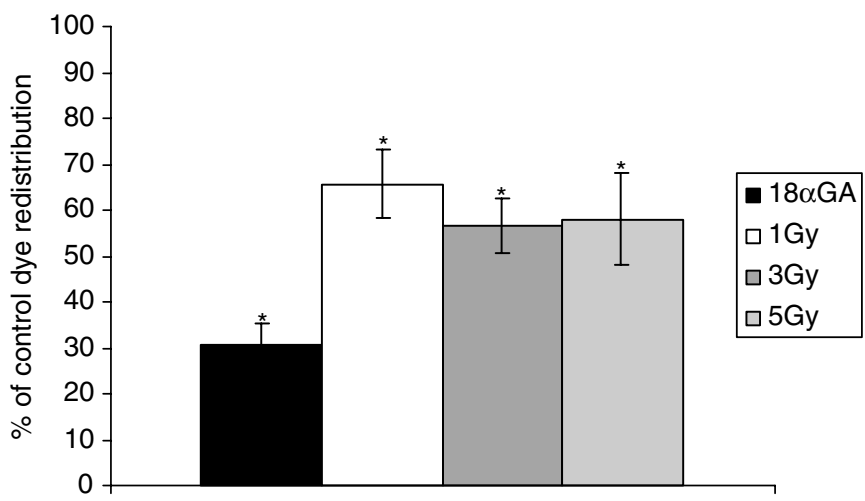

Figure 4 Dose-response relationship of 'bystander' WB-F344 rat liver epithelial cells confluent with irradiated cells at (A) $3 \mathrm{~min}$ and (B) $15 \mathrm{~min}$ postexposure, compared to cells treated with $25 \mu \mathrm{M}$ I $8 \alpha$-glycyrrhetinic acid ( $18 \alpha \mathrm{GA}$; gap junction inhibitor). Results are expressed as $\%$ communication compared to control (untreated) cells $\left(5.022 \cup \mathrm{min}^{-1} \pm 0.275\right)$. Bars show standard error of the mean.

\section{Phosphorylation of Cx43}

Gap junction closure involves hyperphosphorylation of connexins and the phosphorylation of $\mathrm{Cx} 43$ can be detected by altered electrophoretic mobility of the proteins on a Western blot. The phorbol ester and tumour promoter TPA, which is known to induce $\mathrm{Cx} 43$ hyperphosphorylation (Rivedal and Opsahl, 2001; Yang et al, 2001), was used as a positive control to compare with cells irradiated with the ultrasoft X-rays. Western blotting of SDSpolyacrylamide gels revealed a difference in phosphorylation of Cx43 in WB-F344 cells treated with $20 \mathrm{nM}$ TPA for $15 \mathrm{~min}$ and cells irradiated with $5 \mathrm{~Gy}$ ultrasoft $\mathrm{X}$-rays, $15 \mathrm{~min}$ postexposure compared to controls. In Figure 6 , a band of reduced electrophoretic mobility is seen in isolates from cells treated with TPA and $5 \mathrm{~Gy}$ ultrasoft X-rays. This band indicates hyperphosphorylation of $\mathrm{Cx} 43$ in these cells.

\section{Effects of soft X-rays on membrane permeability}

In order to confirm that the observed effects on GJIC were due to cells responding to radiation and not due to secondary effects of loss of membrane integrity and cell death at the time points investigated, membrane permeability was assessed by the leakage of LDH and was found not to be significantly reduced compared to untreated cells $(P=0.27)$ over the times of experiments carried out, nor at $2 \mathrm{~h}$ postexposure. As a positive control, membranes were permeabilised with Triton $\mathrm{X}-100$ and LDH leakage was significantly greater than in untreated cells $(P=0.0004)$.
A
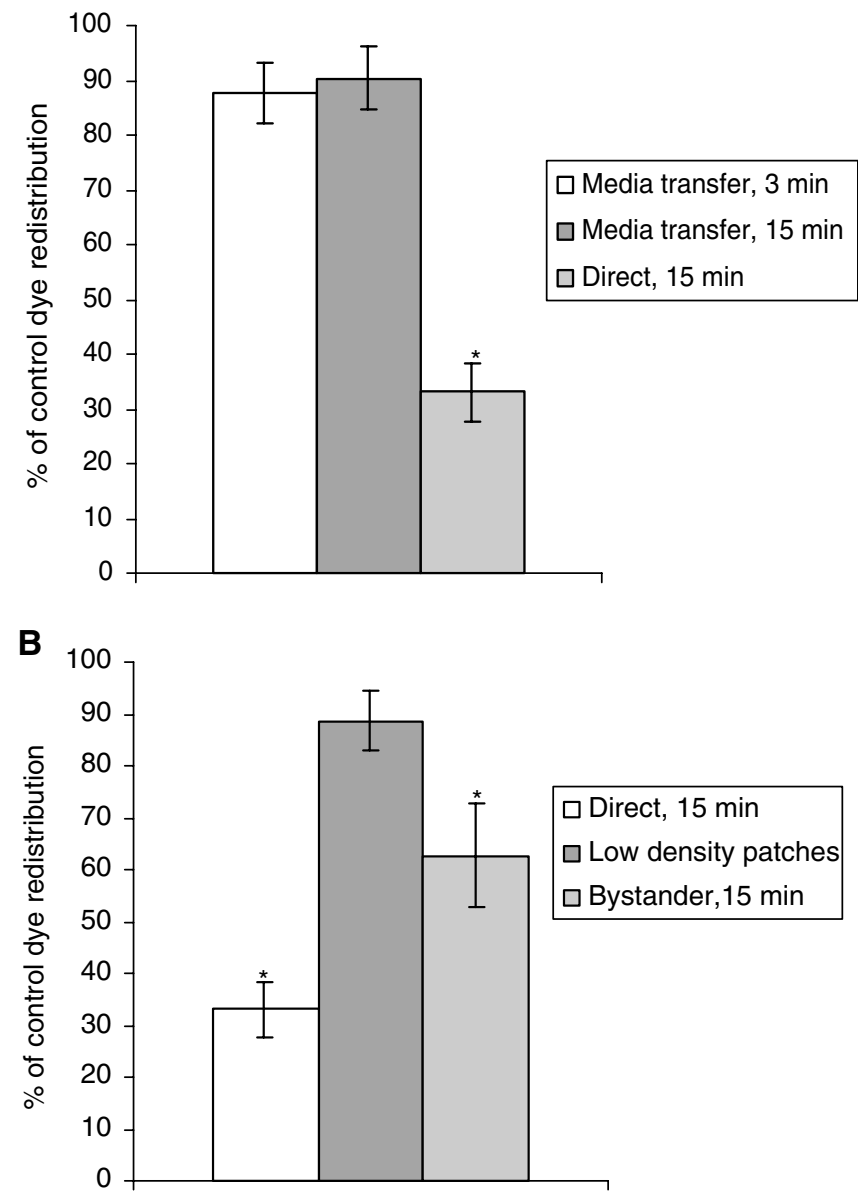

Figure 5 GapFrap in cells nonconfluent with irradiated cells: results are expressed as \% communication compared to control (untreated) cells (5.022 $\left.\mathrm{U} \mathrm{min}^{-1} \pm 0.275\right)$. (A) Within the time domain of the experiment, no transfer of inhibitory molecules occurred by diffusion through the extracellular environment. (B) Confirmation that cells need to be confluent for radiation-induced inhibition of GJIC to occur. Low-density patches of cells were not confluent with directly irradiated (target) cells, and bystander cells were confluent with target cells.

\section{DISCUSSION}

We have developed and combined 'state-of-the-art' techniques in laser plasma X-ray generation, micropositioning and laser photobleaching in biological cells to investigate the effects of ionising radiation on intercellular gap junctions. The experiments illustrate how ionising radiation inhibits GJIC in a dose-dependent manner in directly irradiated cells. Inhibition of GJIC is effective at least up to $15 \mathrm{~min}$ after exposure to ultrasoft X-rays, without a loss of membrane integrity.

Phosphorylation of connexins controls the assembly, operation and degradation of the gap junctions (Lampe and Lau, 2000). When WB-F344 cells were exposed to the tumour promoter TPA, a loss of GJIC was observed and this was associated with increased hyperphosphorylation of $\mathrm{Cx} 43$ (Rivedal and Opsahl, 2001; Yang et al, 2001). This was attributed to the TPA-mediated activation of protein kinase C (Ren et al, 1998), but interaction with the mitogen-activated protein kinase (MAP kinase) pathway may also be necessary (Rivedal and Opsahl, 2001). These changes in phosphorylation appear to result in internalisation of connexins into the cytoplasm, disassembling the gap junctions and cutting off communication between cells (Yang et al, 2001). These changes are 


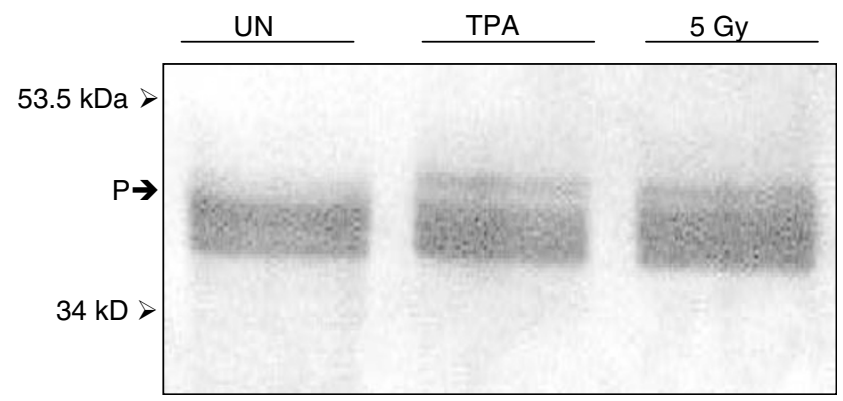

Figure 6 Western blot showing hyperphosphorylation of Cx43 in WBF344 cells exposed to 5 Gy ultrasoft X-rays (5 Gy) and $20 \mathrm{nM}$ TPA. (P) Demarcation of the band showing phosphorylation in irradiated and TPAtreated cells and the absence of such a band in untreated cells (UN).

also observed when cells enter mitosis (Xie et al, 1997) as well as when they enter into apoptosis (Huang et al, 1998, 2001; Koffler et al, 2000). V-src tyrosine protein kinase and casein II kinase have also been shown to phosphorylate certain connexins (Lampe and Lau, 2000; Yin et al, 2001).

Our studies show that the inhibition of communication by ultrasoft X-rays appears to involve the hyperphosphorylation of the gap junction protein $\mathrm{Cx} 43$ in a manner similar to that induced by the tumour-promoting agent TPA. The positive and negative regulation of gap junction communication has previously been demonstrated to be associated with phosphorylation of connexin on serine/threonine and tyrosine residues (Cooper et al, 2000). The regulation of $\mathrm{Cx} 43$ trafficking to the membrane, subsequent formation of gap junction plaques, single channel behaviour and degradation by phosphorylation are represented in many cell types. These events have also been shown to be TPA sensitive and regulated by PKC (Lampe and Lau, 2000). It appears that ionising radiation may have effects similar to TPA and that the phosphorylation of $\mathrm{Cx} 43$ is affected in a similar manner.

Our results demonstrate that a signal causing a reduction in GJIC passes from directly exposed cells to confluent 'bystander' cells within a distance of $100 \mu \mathrm{m}$ from the irradiated cells. This distance represents about five cell diameters. When GJIC is inhibited by radiation in target cells, a reduction in communication (rather than a complete inhibition) still alters the transfer of a damaging signal to bystander cells, albeit in reduced quantities explaining the nonlinear dose response.

Studies using cultured cells have described observations that implicate a factor that is produced by irradiated cells and transferred through the culture medium to nonirradiated cells (Little, 2000; Zhou et al, 2002). The medium-borne factor requires that high numbers of cells be exposed to irradiation before an effect is seen upon recipient cells or that the factors released into the medium are sufficiently concentrated, that is, medium

\section{REFERENCES}

Azzam EI, de Toledo SM, Gooding T, Little JB (1998) Intercellular communication is involved in the bystander regulation of gene expression in human cells exposed to very low fluences of alpha particles. Radiat Res 150: 497-504

Azzam EI, de Toledo SM, Little JB (2001) Direct evidence for the participation of gap junction-mediated intercellular communication in the transmission of damage signals from $\alpha$-particle irradiated to unirradiated cells. Proc Natl Acad Sci USA 98: 473-478

Belakov OV, Malcolmson AM, Folkard M, Prise KM, Michael BD (2001) Direct evidence for a bystander effect of ionising radiation in primary human fibroblasts. Br J Cancer 84: 674-679 transfer effect is dependent on the ratio of cell number to medium volume.

The medium transfer experiments we carried out suggest that the signal is not transferred via the medium (at least not within the time frame of these studies). More importantly, the results of experiments that used nonconfluent patches of cells showed that no reduction of GJIC was seen in patches of cells at a distance of $100 \mu \mathrm{m}$ and separate from irradiated cells. This confirmed that a contiguous link of bystander cells with irradiated cells has to exist before the immediate postirradiation inhibition of GJIC in the former is observed.

In the studies using $\alpha$-particles, the participation of gap junction transfer was established by using inhibitors of gap junction communication. End points that have been measured in the $\alpha$ particle studies are micronucleus formation, expression of the stress-inducible protein $\mathrm{p} 21$ Wafl and phosphorylation of p53 (Azzam et al, 2001). These have all been seen to occur in more cells than would be expected from direct exposure alone (Belakov et al, 2001), and were reduced when cells were incubated with GJIC inhibitors (Azzam et al, 2001).

By targeting the nuclei of cells with a $\alpha$-particle microbeam, mutations at the CD59 locus were seen to accumulate. When the $\alpha$ particle microbeam was focused on the cytoplasm of a cell, free radicals were generated and gave rise to mutations in the nucleus of the same cell (Wu et al, 1999), but these free radicals do not appear to be transferred by the gap junctions to bystander cells (Zhou et al, 2000). This is a reasonable conclusion as the free radical $\mathrm{OH}^{\bullet}$ diffuses no further than $4 \mathrm{~nm}$ before reacting with biomolecules (Chapman et al, 1973). Furthermore, gap junctions can demonstrate charge selectivity, although most gap junction channels favour the transfer of positively charged dyes and ions by a factor of 2-5 (Veenstra, 1996).

Previous reports have demonstrated that radiation-induced stress may propagate between directly irradiated and unexposed cells through gap junctions (Azzam et al, 2001; Huang et al, 2003). The findings reported on in this paper add to these publications, demonstrating that radiation may also inhibit GJIC, perhaps constituting a protective mechanism to prevent the propagation of radiation-induced stress. As radiation may disrupt GJIC, radiation type and dose regimes need to be carefully chosen when combining chemotherapy and radiotherapy in cancer treatment in order to allow the spread of cytotoxic metabolites (Patterson et al, 2003).

In conclusion, the techniques employed herein have enabled us to establish that $\mathrm{Cx} 43$ phosphorylation is associated with loss of GJIC induced by ultrasoft X-ray exposure. Bystander cells also exhibit reduced GJIC with an apparent nonlinear dose dependency, reflecting the role of GJIC itself in the propagation of the inhibitory signal(s) of unknown identity. It should be noted that the level and nature of the bystander effects are likely to be dependent on the cell type (Hall, 2003), possibly due to different connexin expression profiles.
Botchway SW, Stevens DL, Hill MA, Jenner TJ, O’Neill P (1997) Induction and rejoining of DNA double-strand breaks in Chinese hamster V79-4 cells irradiated with characteristic aluminium and copper L ultrasoft X-rays. Radiat Res 148: $317-324$

Chapman JD, Reuvers AP, Borsa J, Greenstock CL (1973) Chemical radioprotection and radiosensitisation of mammalian cells growing in vitro. Radiat Res 56: $291-306$

Chipman JK, Mally A, Edwards GO (2003) Disruption of gap junctions in toxicity and carcinogenicity. Toxicol Sci 71: $146-153$

Cooper CD, Solan JI, Dolejsi MK, Lampe PD (2000) Analysis of connexin phosphorylation sites. Methods 20: 196-204 
Cotrina ML, Lin JHC, Alves-Rodrigues A, Liu S, Li J, Azmi-Ghadimi H, Kang J, Naus CCG, Nedergaard M (1998) Connexins regulate calcium signalling by controlling ATP release. Proc Natl Acad Sci USA 95: $15735-15740$

Evans WH, Martin PE (2002) Gap junctions: structure and function. Mol Membr Biol 19: $121-136$

Frame MK, de Feijter AW (1997) Propagation of mechanically induced intercellular calcium waves via gap junctions and ATP receptors in rat liver epithelial cells. Exp Cell Res 230: 197-207

Goldberg GS, Moreno AP, Bechberger JP, Hearn SS, Shrives RR, MacPhee DJ, Zhang Y, Naus CCG (1996) Evidence that disruption of connexon particle arrangement in gap junction plaques is associated with inhibition of gap junctional communication by a glycyrrhetinic acid derivative. Exp Cell Res 222: 48-53

Goodhead DT, Thacker J (1977) Inactivation and mutation of cultured mammalian cells by aluminium characteristic ultra-soft X-rays. 1 Properties of aluminium X-rays and preliminary experiments with Chinese hamster cells. Int J Radiat Biol 31: $541-559$

Hall EJ (2003) The bystander effect. Health Phys 85: $31-35$

Huang RP, Fan Y, Hossain MZ, Peng A, Zeng ZL, Boynton AL (1998) Reversion of the neoplastic phenotype of human glioblastoma cells by connexin 43 (Cx43). Cancer Res 58: 5089-5096

Huang RP, Hossain MZ, Huang R, Gano J, Fan Y, Boynton AL (2001) Connexin 43 (Cx43) enhances chemotherapy-induced apoptosis in human glioblastoma cells. Int J Cancer 92: 130-138

Huang XF, Lin TY, Gu J, Zhang LD, Roth JA, Liu JS, Fang BL (2003) Cell to cell contact required for bystander effect of the TNF-related apoptosisinducing ligand (TRAIL) gene. Int J Oncol 22: 1241 - 1245

Koffler L, Roshong S, Park IK, Cesen-Cummings K, Thompson DC, Dwyer-Nield LD, Rice P, Mamay C, Malkinson AM, Ruch RJ (2000) Growth inhibition in $\mathrm{G}(1)$ and altered expression of cyclin D1 and p27(kip-1) after forced connexin expression in lung and liver carcinoma cells. J Cell Biochem 79: $347-354$

Laemlli UK (1970) Cleavage of structural proteins during the assembly of the head of bacteriophage T4. Nature 227: 680-685

Lampe PD, Lau AF (2000) Regulation of gap junctions by phosphorylation of connexins. Arch Biochem Biophys 384: 205-215

Little JB (2000) Radiation carcinogenesis. Carcinogenesis 21: $397-404$

Meldrum RA, Edwards GO, Chipman JK, Wharton CW, Botchway SW, Hirst GJ, Shaikh W (2002) A pulsed laser generated soft X-ray source for the study of gap junction communication and 'bystander' effects in irradiated cells. Radiat Homeostasis Int Congr Ser 1236: 289-294

Moldeus P, Hogberg J, Orrenius S (1978) Isolation and use of liver cells. Methods Enzymol 52: 60 -71

Molten FL (1986) Tumour chemosensitvity conferred by inserted herpes thymidine kinase genes. Paradigm for a prospective cancer control strategy. Cancer Res 46: 5276-5280

Mothersill C, Seymour C (2001) Radiation-induced bystander effects: past history and future directions. Radiat Res 155: 759-767

Patterson AV, Saunders MP, Greco O (2003) Prodrugs in genetic chemoradiotherapy. Curr Pharm Des 9: $2131-2154$
Ren P, Mehta PP, Ruch RJ (1998) Inhibition of gap junction intercellular communication by tumour promoters in connexin 43 and connexin 32 expressing liver cells: cell specificity and role of protein kinase C. Carcinogenesis 19: 169-175

Rivedal E, Opsahl H (2001) Role of PKC and MAP kinase in EGF- and TPAinduced connexin43 phosphorylation and inhibition of gap junction intercellular communication in rat liver epithelial cells. Carcinogenesis 22: $1543-1550$

Stock A, Siles H, Stahl W (1998) Enhancement of gap junctional communication and connexin43 expression by thyroid hormones. Biochem Pharmacol 55: 475-479

Tanaka T, Yamasaki H, Mesnil M (2001) Stimulation of intercellular communication of poor-communicating cells by gap-junction-competent cells enhances the HSV-TK/GCV bystander effect in vitro. Int J Cancer 91: $538-542$

Tare M, Coleman HA, Parkington HC (2002) Glycyrrhetinic derivatives inhibit hyperpolarisation in endothelial cells of guinea pig and rat arteries. Am J Physiol Heart Circ Physiol 282: H335-H341

Turcu ICE, O’Neill F, Tallents GJ, Hannon T, Batrini D, Guilietti A, Wharton CW, Meldrum RA (1990) Atmospheric pressure operation of a $\mathrm{KrF}$ laser plasma X-ray source at $1.1 \mathrm{keV}$. SPIE 1278: $820-832$

Turcu ICE, Ross IN, Trenada P, Wharton CW, Meldrum RA, Daido $\mathrm{H}$, Scultz MS, Fluck P, Michette AG, Juna AP, Maldonado JR, Shields H, Tallents GJ, Dwivedi L, Krishnan J, Stevens DL, Jenner T, Batini D, Goodson H (1994) Picosecond excimer laser-plasma source for microscopy, biochemistry and lithography. J Soc Photo-opt InstrEng USA 2015: $243-287$

Veenstra RD (1996) Size and selectivity of gap junction channels formed from different connexins. J Bioenerg Biomembr 28: $327-337$

Willecke E, Eiberger J, Degen J, Eckardt D, Romualdi A, Guldenagel M, Deutsch U, Sohl G (2002) Structural and functional diversity of connexin genes in the mouse and human genome. Biol Chem 383: 725-737

Wu LJ, Randers-Pehrson A, Xu A, Waldren CA, Geard CR, Yu Z, Hei TK (1999) Targeted cytoplasm irradiation with alpha particles induces mutations in mammalian cells. Proc Natl Acad Sci USA 996: 4959- 4964

Xie HQ, Laird DW, Chang TH, Hu VW (1997) A mitosis-specific phosphorylation of the gap junction protein connexin43 in human vascular cells: biochemical characterisation and localisation. I Cell Biol 137: $203-210$

Yang KS, Yun JW, Yoon BS, Lim YK, Lee YS (2001) Preventive effect of germanium dioxide on the inhibition of gap junctional intercellular communication by TPA. Cancer Lett 166: $47-153$

Yin X, Gu S, Jiang JX (2001) The development-associated cleavage of lens connexin 45.6 by caspase-3-like protease is regulated by casein kinase IImediated phosphorylation. J Biol Chem 276: 34567 - 34572

Zhou H, Randers-Pehrson G, Waldren CA, Vannais D, Hall EJ, Hei TK (2000) Induction of a bystander mutagenic effect of alpha particles in mammalian cells. Proc Natl Acad Sci USA 97: 2099-2104

Zhou H, Suzuki M, Geard CR, Hei TK (2002) Effects of irradiated medium with or without cells on bystander responses. Mutat Res 499: 135-141 